Vol. 24, No. 1, Januari 2021, hlm. 20-27

p-ISSN: 1410-9344; e-ISSN: 2549-5631

WARTA LPM

homepage: http://journals.ums.ac.id/index.php/warta

\title{
Optimalisasi Peran Bina Keluarga Melalui Kelas Senam Lansia Kampung KB Pucangsawit, Surakarta
}

\author{
${ }^{1}$ Rina Sri Widayati, Dewi Kartika Sari, Dita Mirawati,Wahyuni \\ Stikes Aisyiyah Surakarta \\ Email: 1rinasriwidayati@gmail.com
}

\section{Article Info}

Submitted: 12 September 2019

Revised: 10 October 2019

Accepted: 15 June 2020

Published: 12 December 2020

Keywords: optimalization, family, gymnatic elderly
Kata kunci: optimalisasi, keluarga, senam lansia

\section{Abstract}

The proportion of the population above 60 years in the world from 2000 to 2050 will double from around $11 \%$ to $22 \%$, or in absolute terms increasing from 605 million to 2 billion elderly. Elderly people are at risk of falling, this is caused by activity factors, decreased physical ability, illness and environmental factors. The results of interviews with the elderly in Pucangsawit Jebres Surakarta Village found that the majority did not yet know the early detection of the risk of falling in the elderly. To provide knowledge to the public about early detection of falling risk in the elderly and can practice balance exercises. The methods applied in community service are socialization and health education regarding the early detection of the risk of falls in the elderly and their management with balance exercises. Community service activities carried out on Thursday 11 July 2019 in Puntadewa Smart Park, Pucangsawit Jebres, Surakarta. Community service activities were attended by 30 people. Observation of community service activities which included health counseling and balance gymnastics training that the majority of participants were active in asking questions and answering questions given by the community service team and were able to practice balance exercises. Providing health education about early detection of falling risk in the elderly has proven that community knowledge and skills increase after counseling is seen from the value of pre-test and post-test community service participants.

Abstrak
Proporsi penduduk di atas 60 tahun di dunia tahun 2000 sampai 2050
akan berlipat ganda dari sekitar 11\% menjadi 22\%, atau secara absolut
meningkat dari 605 juta menjadi 2 milyar lansia. Lansia sangat berisiko
mengalami jatuh, hal ini disebabkan oleh faktor aktivitas, penurunan
kemampuan fisik, penyakit yang diderita, dan faktor lingkungan. Hasil
wawancara dengan lansia di Kelurahan Pucangsawit Jebres Surakarta
didapatkan mayoritas belum mengetahui mendeteksi dini risiko


jatuh pada lansia. Tujuan dari kegiatan ini adalah untuk memberikan pengetahuan kepada masyarakat tentang deteksi dini risiko jatuh pada lansia dan dapat mempraktikkan senam keseimbangan. Metode yang diterapkan dalam pengabdian masyarakat adalah sosialisasi dan pendidikan kesehatan mengenai deteksi dini risiko jatuh pada lansia dan penatalaksanaannya dengan senam keseimbangan. Kegiatan sosialisasi mengenai deteksi risiko tinggi pada lansia dan simulasi senam keseimbangan bagi lansia dilaksanakan pada hari yang sama masyarakat yang telah dilakukan pada hari Kamis tanggal 11 Juli 2019 di Taman Cerdas Puntadewa Kelurahan Pucangsawit Jebres Surakarta. Kegiatan pengabdian masyarakat diikuti oleh 30 orang. Observasi kegiatan pengabdian masyarakat yang meliputi penyuluhan kesehatan dan pelatihan senam keseimbangan bahwa mayoritas peserta aktif dalam mengajukan pertanyaan maupun menjawab pertanyaan yang diberikan oleh tim pengabdian masyarakat serta dapat mempraktikkan senam keseimbangan. Pemberian pendidikan kesehatan tentang deteksi dini risiko jatuh pada lansia telah membuktikan bahwa pengetahuan dan keterampilan masyarakat meningkat setelah diberikan penyuluhan terlihat dari nilai pre dan post test para kader lansia.

\section{PENDAHULUAN}

Lansia adalah seseorang yang mencapai umur >60 tahun (Undang - Undang No.13, 1998, dalam Padila, 2013). Proses penuan dalam perjalanan hidup manusia merupakan suatu hal yang wajar, dan ini akan dialami oleh semua orang yang diberikan umur panjang, hanya cepat dan lambatnya proses tersebut bergantung pada masing-masing individu. Perkembangan manusia dimulai dari masa bayi, anak, remaja, dewasa, tua, dan akhirnya akan masuk pada fase usia lanjut dengan umur diatas 60 tahun (Khalid, 2012).

Badan Pusat Statistik tahun 2013 menyatakan bahwa jumlah penduduk usia 60 tahun ke atas di Indonesia pada tahun 2010 sebesar 7,56\% dan diprediksi pada tahun 2035 mencapai 15,77\% (BPS, 2013). Ditinjau dari tiga provinsi yang memiliki populasi lansia terbesar yakni DI. Yogyakarta (12,99\%), Jawa Timur (10,37\%), Jawa Tengah (10,34\%) (BPS, 2012). Provinsi tersebut pada tahun 2035 bisa dikategorikan sebagai provinsi penduduk tua (aging population) (BPS, 2013).

Menurut World Health Organization (2014), proporsi penduduk di atas 60 tahun di dunia tahun 2000 sampai 2050 akan berlipat ganda dari sekitar $11 \%$ menjadi $22 \%$, atau secara absolut meningkat dari 605 juta menjadi
2 milyar lansia. Nazam (2013) melakukan survei tentang kejadian pasien jatuh di AS, di mana hasil survei tersebut menunjukkan 2,3-7\% per1000 lansia mengalami jatuh dari tempat tidur setiap hari dan 29-48\% lansia mengalami luka ringan dan 7,5\% dengan luka-luka serius. Kongres XII PERSI (2012) melaporkan bahwa angka kejadian pasien jatuh di Indonesia bulan Januari-September 2012 sebesar 14\%, hal ini menggambarkan presentasi angka pasien jatuh masuk ke dalam lima besar insiden medis selain medicine eror (Komariah, 2015).

Perubahan yang terjadi pada sistem muskuloskeletal, yaitu: penurunan massa dan tonus otot, serat otot berkurang ukurannya, kekuatan otot berkurang sebanding dengan penurunan massa otot (Potter \& Perry, 2006). Tulang kehilangan densitas (cairan) dan semakin rapuh, kekuatan dan stabilitas tulang menurun, terjadi kifosis, gangguan gaya berjalan, tendon mengerut dan mengalami sklerosis, atrofi serabut otot, serabut otot mengecil sehingga gerakan menjadi lamban, otot kram, dan menjadi tremor, aliran darah ke otot berkurang sejalan dengan proses menua. Semua perubahan tersebut dapat mengakibatkan kelambanan dalam gerak, langkah kaki yang pendek, kekuatan otot menurun terutama ekstremitas bawah (Darmojo, 2004). Kaki tidak dapat menapak 
dengan kuat dan cenderung mudah goyah, lansia menjadi lambat mengantisipasi bila terjadi gangguan terpeleset, tersandung, mengalami gangguan keseimbangan dan akhirnya berisiko jatuh.

Lansia sangat berisiko mengalami jatuh. Hal ini disebabkan oleh faktor aktivitas, penurunan kemampuan fisik, penyakit yang diderita dan faktor lingkungan (Nugroho, 2008). Sebagian besar jatuh terjadi pada saat lansia melakukan aktivitas berjalan, naik atau turun tangga, merubah posisi atau saat lansia dengan banyak kegiatan dan olahraga yang menyebabkan kelelahan. Penyebab jatuh pada lansia juga bisa karena penyakit yang diderita seperti parkinson, osteoporosis, stroke, dan lain-lain. Sedangkan faktor dari lingkungan adalah lantai yang licin, jalan yang tidak rata, pencahayaan yang kurang, dan tidak adanya handraill pada tangga. Jika lansia mengalami jatuh tentu akan menimbulkan masalah baru dan berdampak pada kesehatan lansia.

Latihan keseimbangan adalah serangkaian gerakan untuk meningkatkan melalui stretching, strengthening (Kloos \& Heiss, 2007). Gerakan latihan keseimbangan mencakup plantar flexi, hip flexi, hip extensi, knee flexi, side leg raise, cawthorne's Head Exercise (eye exercise, eyeear exercise, head exercise). Latihan tersebut membantu otak menyesuaikan dengan perubahan sinyal (re-calibrate) sehingga dengan sendirinya otak akan mampu beradaptasi, proses ini disebut central compensation (Berkshire, 2008). Berdasarkan hal tersebut sehingga dilakukan pengabdian kepada masyarakat melalui tindakan promotif yaitu deteksi dini risiko jatuh pada lansia, tindakan preventif yang diberikan kepada masyarakat yaitu berupa senam keseimbangan.

Berdasarkan hasil pengamatan dan pemeriksaan kepada masyarakat Kelurahan Pucangsawit Surakarta, ada beberapa hal yang menjadi permasalahan kelompok mitra sehingga memiliki keseimbangan tubuh yang kurang baik. Beberapa penyebabnya antara lain yaitu:

1. Padatnya jam kerja yang menjadikan masyarakat tidak punya waktu untuk berolahraga secara rutin.

2. Kurangnya motivasi dan edukasi sehingga masyarakat tidak paham bahaya dan cara mengetahui risiko dini jatuh pada lansia.

\section{METODE}

Kurangnya pengetahuan dan informasi tentang deteksi dini risiko jatuh pada lansia merupakan masalah yang dihadapi. Target kegiatan pengabdian masyarakat ini adalah kader lansia yang di wilayah Kelurahan Pucangsawit Jebres Surakarta dan luaran yang diharapkan dalam kegiatan pengabdian masyarakat ini adalah peserta penyuluhan yang terdiri dari kader lansia mampu memahami deteksi dini risiko jatuh pada lansia. Peserta dapat mempraktikkan senam keseimbangan.

Metode pelaksanaan kegiatan pengabdian masyarakat yang dilakukan menggunakan metode penyuluhan/ pendidikan kesehatan tentang penyakit Deteksi Dini Risiko Jatuh pada Lansia dan pelatihan tentang senam keseimbangan guna menurunkan risiko jatuh pada lansia dengan media musik. Senam keseimbangan terdiri dari 4 tahap yaitu pemanasan, inti 1 , inti 2 , dan pendinginan. Kegiatan ini dilakukan pada tanggal $11 \mathrm{Juli}$ 2019. Pemberian penyuluhan kesehatan tentang Risiko Jatuh pada Lansia meliputi: pengertian lansia, pembagian lansia, pengertian jatuh, faktor penyebab jatuh, akibat jatuh, dan edukasi untuk menurunkan risiko jatuh pada lansia. Metode pelatihan dalam kegiatan pengabdian masyarakat dilakukan dengan cara mempraktikkan senam bersama para kader lansia dan dipimpin oleh mentor.

Kerangka pemecahan masalah melalui usulan pengabdian masyarakat adalah sebagai berikut :

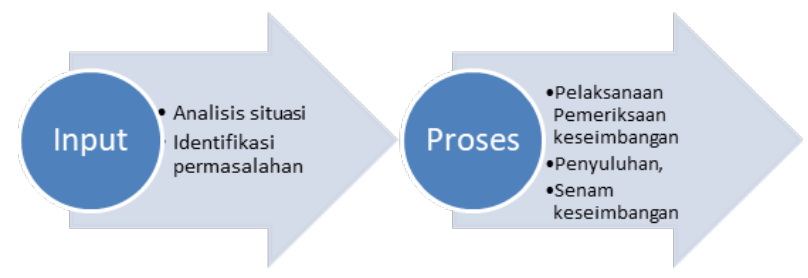

Gambar 1 Kerangka pemecahan masalah pengabdian masyarakat berbasis sistem 


\section{HASIL DAN PEMBAHASAN}

Pada kegiatan pengabdian masyarakat yang telah dilakukan pada hari Kamis tanggal 11 Juli 2019 di Taman Cerdas Puntadewa Kelurahan Pucangsawit Jebres Surakarta. Kegiatan pengabdian masyarakat diikuti oleh 30 kader lansia Kelurahan Pucangsawit. Berupa sosialisasi pelatihan dengan tema tentang Deteksi Dini Risiko Jatuh pada Lansia. Pelaksanaan sosialisasi dan pelatihan kesehatan dimulai kurang lebih pukul 09.00 sampai dengan pukul 12.00, yang diawali dengan pembukaan dan sambutan oleh ketua pelaksana yaitu, Rina Sri Widayati, S.KM., M.Kes dan Kepala Desa Pucangsawit Dyah Saraswati, setelah sambutan dilanjutkan dengan inti acara yaitu penyluhan dan pelatihan.

Sosialisasi materi tentang Deteksi Dini risiko jatuh pada lansia yang meliputi pemberian materi tentang definisi lanjut usia, risiko jatuh pada lansia, faktor risiko jatuh, akibat jatuh, penatalaksanan, asesmen imobilitas lansia, asesmen risiko jatuh, formulir pengkajian risiko jatuh oleh Dita Mirawati dan Rina Sri Widayati.

Kurang pengetahuan dan keterampilan kader lansia mengenai materi kesehatan lansia menjadi masalah yang perlu kami pecahkan dengan solusi diantaranya sosialisasi materi kepada kader kesehatan. Pengukuran tingkat pengetahuan kader mengenai kesehatan lansia dengan metode pemberian kuesioner

Sosialisasi Deteksi Dini Risiko Jatuh pada Lansia dihadiri oleh Kader Lansia Kelurahan Pucangsawit sejumlah 30 orang. Sebelum mulai pelatihan, terlebih dulu para Kader diharuskan mengerjakan soal pre-test pengetahuan seputar risiko jatuh pada lansia. Setelah mengerjakan pre-test, para kader lansia dibagi menjadi 3 kelompok kecil dengan metode small group discussion yang dimentori oleh tim pengabdian masyarakat dengan dibantu 6 mahasiswa.

Dilanjutkan kegiatan small group discussion dilakukan secara ringan guna menanamkan kepadakader lansia mengenai pentingnya deteksi dini risiko jatuh pada lansia. Setelah dilakukan brainstorming dan diskusi kemudian dilakukan pemeriksaan secara general keseimbangan pada kader lansia.

Menurut World Health Organisation (WHO), lansia adalah seseorang yang telah memasuki usia 60 tahun ke atas. Lansia merupakan kelompok umur pada manusia yang telah memasuki tahapan akhir dari fase kehidupannya. Kelompok yang dikategorikan lansia ini akan terjadi suatu proses yang disebut Aging Process atau proses penuaan.

Proses penuaan adalah siklus kehidupan yang ditandai dengan tahapan-tahapan menurunnya berbagai fungsi organ tubuh, yang ditandai dengan semakin rentannya tubuh terhadap berbagai serangan penyakit yang dapat menyebabkan kematian misalnya pada sistem kardiovaskuler dan pembuluh darah, pernafasan, pencernaan, endokrin, dan lain sebagainya. Hal tersebut disebabkan seiring meningkatnya usia sehingga terjadi perubahan dalam struktur dan fungsi sel, jaringan, serta sistem organ. Perubahan tersebut pada umumnya mengaruh pada kemunduran kesehatan fisik dan psikis yang pada akhirnya akan berpengaruh pada ekonomi dan sosial lansia. Sehingga secara umum akan berpengaruh pada activity of daily living (Fatmah, 2010).

Jatuh merupakan suatu kejadian yang dilaporkan penderita atau saksimata, yang melihat kejadian mengakibatkan seseorang mendadak terbaring/terduduk di lantai/tempat yang lebih rendah dengan atau tanpakehilangan kesadaran atau luka (Darmojo, 2004).

Tabel 1. Hasil Pre test dan post test

\begin{tabular}{clcc}
\hline No & Indikator pertanyaan & Pre test & Post test \\
\hline 1 & Definisi lansia & $100 \%$ & $100 \%$ \\
\hline 2 & $\begin{array}{l}\text { Faktor intrinsik } \\
\text { penyebab jatuhnya lansia }\end{array}$ & $20 \%$ & $63 \%$ \\
\hline 3 & $\begin{array}{l}\text { Faktor risiko jatuh pada } \\
\text { lansia }\end{array}$ & $93 \%$ & $96 \%$ \\
\hline 4 & $\begin{array}{l}\text { Faktor yang } \\
\text { mempengaruhi } \\
\text { keseimbangan lansia }\end{array}$ & $100 \%$ & $100 \%$ \\
\hline 5 & Akibat jatuh pada lansia & $70 \%$ & $86 \%$ \\
\hline 6 & Gangguan keseimbangan & $40 \%$ & $53 \%$ \\
\hline 7 & Gangguan psikologis & $90 \%$ & $100 \%$ \\
\hline 8 & Lansia goal & $43 \%$ & $93 \%$ \\
\hline 9 & $\begin{array}{l}\text { Dampak } \\
\text { ketidakseimbangan }\end{array}$ & $83 \%$ & $93 \%$ \\
\hline 10 & Fansia & $100 \%$ & $100 \%$ \\
\hline
\end{tabular}


Jatuh merupakan suatu kejadian yang menyebabkan subyek yang sadar menjadi berada di permukaan tanah tanpa disengaja. Dan tidak termasuk jatuh akibat pukulan keras, kehilangan kesadaran, atau kejang. Kejadian jatuh tersebut adalah dari penyebab yang spesifik yang jenis dankonsekuensinya berbeda dari mereka yang dalam keadaan sadar mengalami jatuh (Stanley, 2006).

Faktor-faktor lingkungan yang menyebabkan jatuh adalah penerangan yang tidak baik (kurang atau menyilaukan), lantai yang licindan basah, tempat berpegangan yang tidak kuat/tidak mudah dipegang dan alat-alat atau perlengkapan rumah tangga yang tidak stabil dan tergeletak di bawah. (Darmojo, 2004).

Jatuh dapat mengakibatkan berbagai jenis cedera, kerusakan fisik, dan psikologis. Kerusakan fisik yang paling ditakuti dari kejadian jatuh adalah patah tulang panggul. Jenis fraktur lain yang sering terjadi akibat jatuh adalah fraktur pergelangan tangan, lengan atas dan pelvis, serta kerusakan jaringan lunak. Dampak psikologis adalah walaupun cedera fisik tidak terjadi, syok setelah jatuh dan rasa takut akan jatuh lagi dapat memiliki banyak konsekuensi termasuk ansietas, hilangnya rasa percaya diri, penbatasan dalam aktivitas sehari-hari, falafobia atau fobia jatuh (Stanley, 2006).

Identifikasi faktor resiko ada setiap lanjut usia perlu dilakukan pemeriksaan untukmencari adanya faktor instrinsik risiko jatuh, perlu dilakukan assessment keadaan sensorik, neurologis, muskuloskeletal dan penyakitsistemik yang sering menyebabkan jatuh. Keadaan lingkungan rumah yang berbahaya dan dapat menyebabkan jatuh harus dihilangkan. Penerangan rumah harus cukuptetapi tidak menyilaukan. Lantai rumah datar, tidak licin, bersih dari benda-benda kecil yang susah dilihat, peralatan rumah tangga yang sudah tidak aman (lapuk, dapat bergerser sendiri) sebaiknya diganti, peralatan rumah ini sebaiknya diletakkan sedemikian rupa sehingga tidak mengganggu jalan/tempat aktivitas lanjut usia. Kamar mandi dibuat tidak licin, sebaiknya diberi pegangan pada dindingnya, pintu yang mudah dibuka. WC sebaiknya dengan kloset duduk dan diberi pegangan di dinding.
Pelatihan latihan keseimbangan bagi lansia dilakukan setelah sosialisasi materi risiko jatuh lansia. Kegiatan dilakukan oleh tiga fasilitator dan enam mahasiswa yang mendampingi senam keseimbangan.

Proses Menua merupakan suatu keadaan yang terjadi di dalam kehidupan manusia. Proses menua bukanlah suatu penyakit melainkan menua merupakan proses menghilangnya secara perlahan kemampuan jaringan tubuh untuk mempertahankan struktur dan fungsi normal (Darmojo, 2009). Proses penuaan ditandai dengan terjadinya kehilangan jaringan pada susunan saraf, otot, dan jaringan lain secara perlahan sehingga tubuh mati sedikit demi sedikit (Mubarak, 2009; Nugroho, 2008). Keseimbangan tubuh dan peningkatan risiko jatuh (Pudjiastuti, 2003).

Gangguan keseimbangan dan jatuh merupakan salah satu masalah pada lansia. Gunarto (dalam Kusnanto, 2007) menyatakan bahwa 31\%-48\% lansia jatuh karena gangguan keseimbangan. Akibat yang ditimbulkan oleh jatuh seperti cedera kepala maupun cedera jaringan lunak. Kejadian jatuh dilaporkan terjadi pada sekitar 30\% orang berusia 65 tahun ke atas setiap tahunnya, dan 50\% dari mereka yang berusia 80 tahun ke atas (Setiati, 2006; Melzer et al, 2004).

Salah satu upaya yang dapat dilakukan untuk mengatasi gangguan keseimbangan dan kejadian jatuh adalah dengan melakukan aktivitas fisik yang teratur dan terprogram. Beberapa aktivitas fisik yang aman untuk lansia, antara lain berjalan kaki dan jogging. Aktivitas tersebut bila dilakukan secara teratur dapat mengurangi gangguan keseimbangan pada lansia. Namun, dari setiap aktivitas tersebut

Salah satu perubahan anatomi pada sistem muskuloskeletal yang terjadi pada proses menua adalah berkurangnya massa otot, degenerasi miofibril, tendon mengerut, dan atrofi serabut otot (Pudjiastuti, 2003; Maryam, 2008). Perubahan anatomi tersebut berdampak pada penurunan kekuatan otot. Kekuatan otot merupakan komponen utama dari keseimbangan tubuh (Guccione, dalam Kusnanto, 2007). Penurunan kekuatan otot mengakibatkan penurunan kemampuan mempertahankan. 
Hasil tersebut sesuai dengan penelitian Herawati dan Wahyuni (2004) yang mendapatkan hasil bahwa terdapat perbedaan yang signifikan antara keseimbangan lansia sebelum dan sesudah diberikan senam lansia. Hal tersebut menguatkan teori yang menyebutkan bahwa manfaat senam lansia adalah meningkatkan salah satu komponen kesegaran jasmani yang berkaitan dengan keterampilan motorik yaitu keseimbangan tubuh (Harsuki, 2010; Sumintarsih, 2006).

Menurut Tinetti (1992), yang dikutip dari Darmojo (2004), ada 3 usaha pokok untuk pencegahan jatuh yaitu :

a. Identifikasi faktor risiko

Pada setiap lanjut usia perlu dilakukan pemeriksaan untuk mencari adanya faktor instrinsik risiko jatuh, perlu dilakukan assessment keadaan sensorik, neurologis, muskuloskeletal, dan penyakit sistemik yang sering menyebabkan jatuh. Keadaan lingkungan rumah yang berbahaya dan dapat menyebabkan jatuh harus dihilangkan. Penerangan rumah harus cukup tetapi tidak menyilaukan. Lantai rumah datar, tidak licin, bersih dari benda-benda kecil yang susah dilihat, peralatan rumah tangga yang sudah tidak aman (lapuk, dapat bergerser sendiri) sebaiknya diganti. Peralatan rumah ini sebaiknya diletakkan sedemikian rupa sehingga tidak mengganggu jalan/tempat aktivitas lanjut usia. Kamar mandi dibuat tidak licin sebaiknya diberi pegangan pada dindingnya, pintu yang mudah dibuka. WC sebaiknya dengan kloset duduk dan diberi pegangan di dinding. b. Penilaian keseimbangan dan gaya berjalan (gait)

Setiap lanjut usia harus dievaluasi bagaimana keseimbangan badannya dalam melakukan gerakan pindah tempat, pindah posisi. Bila goyangan badan pada saat berjalan sangat berisiko jatuh, maka diperlukan bantuan latihan oleh rehabilitasi medis. Penilaian gaya berjalan juga harus dilakukan dengan cermat, apakah kakinya menapak dengan baik, tidak mudah goyah, apakah penderita mengangkat kaki dengan benar pada saat berjalan, apakah kekuatan otot ekstremitas bawah penderita cukup untuk berjalan tanpa bantuan. Kesemuanya ituharus dikoreksi bila terdapat kelainan/ penurunan.

c. Mengatur/ mengatasi faktor situasional.

Faktor situasional yang bersifat serangan akut yang diderita lanjut usia dapat dicegah dengan pemeriksaan rutin kesehatan lanjut usia secara periodik. Faktor situasional bahaya lingkungan dapat dicegah dengan mengusahakan perbaikan lingkungan, faktor situasional yang berupa aktivitas fisik dapat dibatasi sesuai dengan kondisi kesehatan lanjut usia. Aktivitas tersebut tidak boleh melampaui batasan yang diperbolehkan baginya sesuai hasil pemeriksaan kondisi fisik. Maka dianjurkan lanjut usia tidak melakukan aktivitas fisik yang sangat melelahkan atau berisiko tinggi untuk terjadinya jatuh.

Hal tersebut tersebut menunjukkan bahwa senam lansia dapat digunakan sebagai alternatif dalam memberikan intervensi

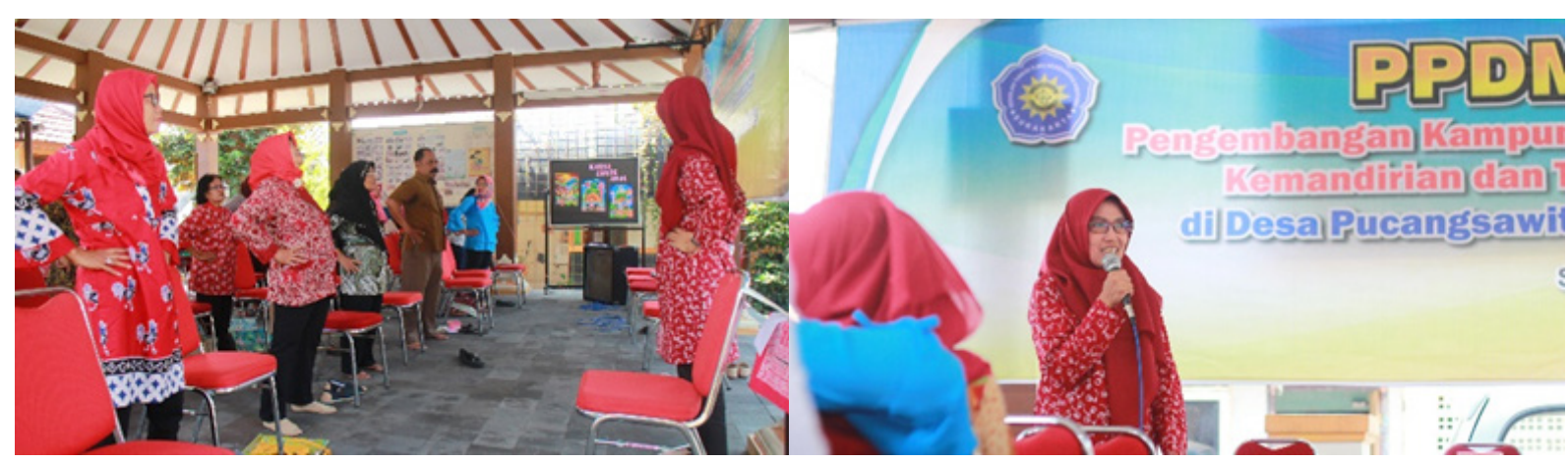

Gambar 2. Pelatihan stimulasi risiko jatuh oleh kader kesehatan Pucangsawit 
pada lansia khususnya bagi lansia yang mengalami gangguan keseimbangan. Menurut para peneliti dari British Journal of Sports Medicine pada tahun 2014, orang lanjut usia, atau lansia, yang aktif bergerak dan berolahraga terbukti lebih sehat dan memiliki risiko yang lebih kecil terhadap penyakit kronis. Selain itu, lansia yang aktif bergerak juga lebih sedikit menderita gangguan kognitif, fungsi fisik, dan mentalnya juga masih terbilang baik ketimbang yang jarang olahraga. Senam lansia bisa menjadi salah satu cara bagi para lanjut usia ini untuk menggerakkan tubuhnya dan Senam juga bisa menjadi terapi fisik yang efektif bagi para manula. Senam yang diiringi musik bisa meningkatkan kemampuan berjalan dan keseimbangan para lansia, menurut Jurnal Science Daily yang diterbitkan pada April 2010. (https://hellosehat.com/hidup-sehat/ kebugaran/senam-lansia-untuk-kebugaran/) .

Lansia merupakan kelompok yang rentan mengalami masalah kesehatan akibat perubahan anatomi dan penurunan fungsi organ. Hal tersebut terjadi karena adanya akumulasi radikal bebas dalam tubuh yang semakin menumpuk seiring dengan meningkatnya usia, sehingga menyebabkan degenerasi sel dan kerusakan jaringan yang mempengaruhi kemampuan fungsional tubuh, salah satunya penurunan kekuatan otot penopang tubuh yang berfungsi sebagai efektor dan berperan dalam pengaturan mekanisme keseimbangan tubuh melalui ankle strategy, hip strategy, dan stepping strategy (Darmojo, 2009; Suhartono, 2005).

Untuk mempertahankan kekuatan otot agar tetap optimal dapat dilakukan melalui olahraga teratur dan memadukan gerak dengan latihan kekuatan otot dan kelenturan seperti senam lansia. Gerakan-gerakan senam lansia akan memicu kontraksi otot, sehingga sintesis protein kontraktil otot berlangsung lebih cepat dari penghancurannya. Hal ini meningkatkan filamen aktin dan miosin di dalam miofibril sehingga massa otot bertambah. Peningkatan ini disertai dengan peningkatan komponen metabolisme otot yaitu ATP yang berdampak pada peningkatan kekuatan otot. Kekuatan otot optimal akan membantu lansia mempertahankan keseimbangan tubuhnya melalui strategi postural (Guyton, 2007; Kusnanto, 2007; Sherwood, 2001).

\section{SIMPULAN}

Kegiatan pengabdian masyarakat tentang deteksi dini risiko jatuh pada lansia dengan pelatihan senam keeseimbangan telah dilaksanakan pada tanggal 11 Juli 2019 di Taman Cerdas Puntadewa Kelurahan Pucangsawit Jebres Surakarta. Hasil yang didapatkan adalah tercapainya target luaran yang berupa peningkatan pengetahuan dan pemahaman kader lansia tentang risiko jatuh pada lansia dan pelatihan senam keseimbangan. Peserta mengalami peningkatan pengetahuan dari hasil pre test dan pos test dalam upaya menurunkan risiko jatuh pada lansia. Setelah adanya kegiatan penyuluhan kesehatan tentang risiko jatuh pada lansia ini dapat direkomendasikan untuk dijadikan program rutin di masyarakat dengan pemberian senam keseimbangan guna menurunkan risiko jatuh pada lansia.

\section{UCAPAN TERIMA KASIH}

Terima kasih kepada Ristekdikti yang telah memberikan hibah PPDM "Pengembangan kampung KB Berbasis kemandirian dan teknologi di Pucangsawit, Surakarta. Kami juga mengucapkan terimakasih kepada Kalurahan Pucangsawit yang sudah berkenan menjadi mitra dalam kegitan pengabdian kali ini.

\section{DAFTAR PUSTAKA}

Bahtiyar, Lutfi (2011) GDS: Hadi dan Kris Pranaka. 2010. Buku Ajar Boedhi Darmojo GERIATRI. Jakarta: Fakultas Kedokteran Universitas Indonesia.

Berkshire. 2008. Balance Exercise; dari www.royalberkshire.nhs.uk diakses 19 Juli 2019

BPS. (2013). Penduduk Lanjut Usia. Diambil dari http://www.menegpp.go.id/v2/index.php/ datadaninformasi/kependudukan

Darmojo, B. (2009). Buku Ajar Geriatri (Ilmu Kesehatan Usia Lanjut). Jakarta: FKUI 
Fatmah. 2013. Masalah Gizi Usia Lanjut: Upaya Penelitian \& Pengembangan. dalam Memanusiakan Lanjut Usia Penuaan Penduduk \& Pembangunan di Indonesia. Yogyakarta: SurveyMeter.

Guyton, A.C. and Hall J.E. (2007). Buku Ajar Fisiologi Kedokteran. Edisi 10. Jakarta: EGC

Novita Joseph. Manfaat Senam Lansia untuk Tingkatkan Kebugaran (https://hellosehat.com/hidupsehat/kebugaran/senam-lansia-untuk-kebugaran/)

Herawati, I dan Wahyuni. (2004). Perbedaan Pengaruh Senam Otak dan Senam Lansia Terhadap Keseimbangan Pada Orang Lanjut Usia. Infokes,

Kloos A D dan Heiss D G. 2007. Exercie for Impaired Balance. Kisner C \& Colby L.A 5thed. Therapeutic Exercise. Philadelphia

Kusnanto. (2007). Peningkatan Stabilitas Postural Pada Lansia Melalui Balance Exercise, (Media Ners, Volume 1, Nomor 2, Oktober 2007)

Komariah, S. 2015. Peran Perawat Dalam Menurunkan Insiden Keselamatan Pasien Jatuh.[Online] available: $\quad$ http://manajemenrumahsakit.net/files/siti\%20komariah\%20_peran\%KEP\%20 dalam\%20IKP.pdf [19 Juli 2019]

https://digilib.esaunggul.ac.id/public/UEU-Undergraduate-6046-bab1.pdf. Kejadian Jatuh pada Lansia

Madureira MM, Takayama L, Gallinaro AL, Caparbo VF, Costa RA, Pereira RMR. 2006. Balance Training Program Is Highly Effective In Improving Functional Status And Reducing The Risk Of Falls In Elderly Women With Osteoporosis : A Randomize Controlled Trial. San Paulo: International Osteoporosis Foundation And National Osteoporosis Foundation. 18: 419- 425

Maryam. (2008). Mengenal Usia Lanjut dan Perawatannya. Jakarta: Salemba Medika

Meril,dkk.2016. Pengaruh Senam Lansia Terhadap Keseimbangan Tubuh pada Lansia di Lingkungan Dajan Bingin Sading. Jurnal Keperawatan Community of Publishing in Nursing Ners volume 4 no 1 April (2016) hal 24-27.

Mubarak. (2009). Ilmu Keperawatan Komunitas dan Aplikasi Buku 2. Jakarta: Salemba Medika

Nugroho (2008). Keperawatan Gerontik. Buku Kedokteran EGC: Jakarta.

Pavlou M. 2010. Principle of Vestibular Rehabilitation; diakses dari www.elearningdigital.com/will/ principle_of_Vestibular_Rehabilitation/Prin ciples_of_Vestibular_Rehabilitation_print.html [18 Juli 2019]

Potter, Perry, (2006), Buku Ajar Fundamental Keperawatan: Konsep, Proses dan Praktik, Edisi 4, Volume 2, Alih Bahasa Renata Komalasari, Editor Monica Ester, dkk, Jakarta: EGC

Pudjiastuti \& Utomo. 2003. Fisioterapi pada Lansia. Jakarta: EGC

Sumintarsih. (2006). Kebugaran Jasmani Untuk Usia Lanjut. Yogyakarta: UPN Veteran 